\title{
11
}

\section{Virtue Ethics, Values of the Founders, and Organizational Growth}

\author{
Josh Wei-Jun Hsueh
}

\section{Introduction}

Family businesses, defined as companies held by few members of the founding family through controlling the corporate governance structures, including ownership, management, and/or board (Astrachan et al. 2002), have been one of the main contributors to global economic development and employment. This business form can accommodate up to $80 \%$ of the registered enterprises in Europe (Mandl 2008) and employ $60 \%$ of the workforces in the United States (Astrachan and Shanker 2003). A recent PwC survey (2016) indicates that the total value of family businesses across 50 countries can account for 500 billion US dollars. More interestingly, this business form tends to sustain across generations (Chua et al. 1999). To achieve such a transgenerational sustainability, the controlling family pays attention to

\footnotetext{
J. W.-J. Hsueh ( $\square)$

University of St. Gallen, St. Gallen, Switzerland e-mail: josh.hsueh@unisg.ch

(C) The Author(s) 2020 
the long-term financial and non-financial assets, resulted from various stable stakeholder relationships, such as communities, governments, and the public (Feliu and Botero 2016).

Family business scholars have looked at the motivation behind a family business's sustainability strategy that integrates the firm's responses to multiple stakeholder groups (Le Breton-Miller and Miller 2016). They tend to rely on the construct of socio-emotional wealth (SEW) to denote the difference between the motivations of family and non-family firms (e.g., Berrone et al. 2010; Deephouse and Jaskiewicz 2013; Gómez-Mejía et al. 2007). SEW represents the pursuit of a family business for long-term and non-financial utilities, such as the family's affective connection to the firm, the reputation concern, and the maintenance of the power and influence in the firm structures (Gomez-Mejia et al. 2011; Martin and GomezMejia 2016). Instead, non-family firms are driven by the pursuit of financial returns, especially short-term profits and maximization of the shareholder returns. Family business scholars argue that the pursuit of SEW can trigger a family business's sustainability activities to achieve various long-term non-financial benefits, such as reputation and stakeholders' supports (Cennamo et al. 2012; Gomez-Mejia et al. 2011). However, empirically, there is mixed evidence regarding the sustainability activities of family businesses, such as the governance, employee, and community practices (e.g., Block and Wagner 2014a; Cruz et al. 2014; Du 2015; Labelle et al., 2018), suggesting an incomplete theorization for the link between those drivers and sustainability strategy of a family firm.

This chapter provides a theoretical model to explore the potential mechanisms behind family businesses' mixed sustainability strategy. The model presents a potential dynamic between a family business's strategic motivations - financial and SEW goals, depending on the life cycle of a family business. Then, this chapter proposes several directions for the application of the model with theoretical extension and empirical suggestions to examine how other family and firm characteristics may interact with the model, determining a family firm's strategic decision addressing various stakeholder groups. This chapter highlights 
the importance of temporal shift in the controlling family's strategic goals (Holt et al. 2017) that account for the heterogeneous sustainability strategy of family businesses.

\section{Theoretical Background}

\subsection{The Difference Between Family Business and Non-family Business-SEW as Non-financial Goals}

Family businesses are characterized by the dominance of few members of the founding family in the firm structure through holding the majority of ownership, controlling the voting rights in the board, and possessing several top managerial positions (Astrachan et al. 2002). In addition to the significant control of the firm structures, the controlling family tends to have the intention to transfer these controls to the next generation (Chua et al. 1999). Compared to non-family businesses which tend to focus on merely financial goals, particularly short-term profitability and returns on investments (Carney et al. 2015), family businesses are influenced by the both the financial and non-financial goals that are related to this family involvement in the firm. For instance, they would have a more careful financial plan and pay more attention to the family's non-financial assets, such as reputation and social relationships, to sustain the family control over generations (Hammond et al. 2016). Family business scholars tend to use the SEW construct to capture these specific characteristics of family businesses, particularly those related to the family's non-financial goals.

The construct of SEW is first proposed by Gómez-Mejía and colleagues (2007) to denote the non-financial goals of family businesses. They examined Spanish olive oil mills from 1944 to 1998 and found family-owned mills were less likely to join cooperatives that could increase the firm's financial performance but would cost the family's control of the firm. They proposed that this decision is driven by "socio-emotional wealth," the controlling family's affective needs to maintain its control of 
the firm as a family dynasty. Later, Berrone and others (2012) proposed a theoretical framework called FIBER model to capture all the potential non-financial goals of a family business. It includes (1) family control and influence through ownership and management; (2) identification with the firm which name is closely tied to the family name; (3) binding social ties between the family and other non-family stakeholders; (4) emotional attachment of the family that transfers the interpersonal relationships to the firm; (5) renewal of the family dynasty that persists across generations. This model provides a framework to examine how various non-financial goals may affect a family firm's strategic decisions, including sustainability strategy (Hauswald and Hack 2013).

However, existing studies have mixed evidence regarding how SEW goals affect sustainability activities of a family firm. Although some studies show positive evidence, such as better environmental performance (Berrone et al. 2010), more philanthropic donations (Campopiano et al. 2014), and greater community involvement (Peake et al. 2017), others have shown negative results. For instance, McGuire et al. (2012) used the American sample from the Kinder, Lindenberg, and Domini (KLD) database ${ }^{1}$ in 2000 and found the negative effect of family dominance in the firm's governance structure on its sustainability activities. Another study of Cruz and colleagues (2014) looked at public firms in Europe and found that family firms perform worse than non-family counterparts in terms of governance and employee practices to maintain the family control and emotional attachment. Similarly, Labelle and others (2018) used the sample of firms from multiple developed countries and found that the over-concentration of family ownership prevents a family firm from investing in sustainability activities. The inconclusive evidence in the existing literature indicates that we probably need to consider other potential factors that may alter the influence of SEW goals on sustainability activities of a family business (Le Breton-Miller and Miller 2016).

\footnotetext{
${ }^{1}$ One of the most commonly used database in existing studies to look at corporate sustainability activities, including practices addressing issues related to community, diversity, employees, environment, product and services (Carroll et al. 2016; Harrison and Freeman 1999). Now, it is renamed as MSCI ESG database.
} 
Strategic goals

Aligned financial \& SEW goals - survival

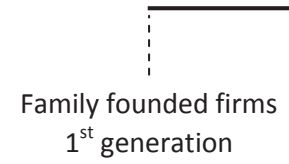

Life stage
Potential conflicts between financial \& SEW goals - growth vs. control
Balance between financial \& SEW goals long-term benefits

Fig. 1 The dynamic between different strategic goals of a family firm along its life stages

\section{A Temporal Framework-The Dynamic Between SEW and Financial Goals}

To examine how the strategic goals of a family firm have alternating influences on its sustainability activities, this chapter introduces the temporal factor to point out how SEW and financial goals interact along with the life cycle of a family firm. As family businesses are characterized by the long-term horizon across generations (Gomez-Mejia et al. 2011), the examination of a family firm's life stage enables us to have a better examination about how its sustainability activities evolve along time, especially when corporate sustainability is supposed to be a strategy addressing stakeholder relationships in long run (Eccles et al. 2014). Following the life stage model of Le Breton-Miller and Miller (2013), the proposed framework, presented in Fig. 1, looks at three stages: founding stage, post-founder stage, and cousin consortia stage.

\subsection{Founding Stage-Aligned SEW and Financial Goals for Firm Survival}

At the founding stage, the first generation of the family needs to go through several entrepreneurial processes to begin the business. Cardon and colleagues (2005) use the parenthood metaphor to illustrate these 
processes. The founding family, as the parent, first has the entrepreneurial idea and starts to make commitments to commercially realize such an idea. They go through various start-up processes, including obtaining venture capital, developing business plans, negotiating with suppliers, and sort through the legal requirement to start-up the venture. After the firm starts the business, the parents need to nurture their child, i.e., the firm, to grow and become independent, i.e., having profits to continue the operation on its own without overreliance on the founders' personal resources (Cassar 2007). At this stage, the founding family primarily focuses on building the foundation for the firm to survive on its own (Miller and Friesen 1984).

For a family business at this stage, the SEW goals is believed to align with the financial goals - the firm survival. The SEW comes from the founding family's treatment of the firm as if it is their child (Cardon et al. 2005). The founders have high emotional attachment to the firm when they put in personal capitals and commitments, including eliciting financial and human resources of their personal networks and being involved in the daily decision-making processes (Gersick 1997). Founders are similar to parents, who tend to hope that their children can survive and grow to become independent adults, in this case, an independent firm that can thrive in the market. To survive, the children need to have the financial means to survive the environment, i.e., profits to sustain the operation in long run. Therefore, the founding family tends to pay most of their attention to the financial stability of the firm so that the firm can sustain itself in the future (Cooper 1981).

This alignment of SEW and financial goals for the survival of a family business at the founding stage is likely to develop its sustainability activities based on the cost-benefit analysis. The sustainability strategy is likely to be focused on economic issues (Cennamo et al. 2012). For instance, instead of increasing the diversity practices in the governance structure or human resource recruitment, a family business is likely to target activities that can facilitate the business operation on the market (Zientara 2017). The firm may comply with the regulations for the minimal wage to ensure employees' basic livelihood, and there is no violation of labor right rules (Spence 2016), without going further on improving employees' benefits. Instead, the firm is willing to invest in 
marketing campaign about the environmental attributes of its products or services, such as limited greenhouse gas emission or reduced use of chemical substance, since marketing campaigns can boost customers' purchase, even if the firm may not actually implement any practice to improve its environmental footprint along the operational process (Gond et al. 2009). Thus, a family business at its founding stage may limit its sustainability strategy to activities that can facilitate the firm survival, such as avoiding the regulatory violation and directly improving market returns.

Proposition 1: Sustainability strategy of a family business at the founding stage is limited to those with direct financial returns.

\subsection{Post-founder Stage-Potential Conflict Between SEW and Financial Goals}

In the next stage after founders have left the firm, a family business is passed to the following generation. Several family members, normally with the sibling relationships, share the ownership and management controls of the firm (Gersick 1997). Instead of holding the parenthood mind-set, the controlling family members in this stage have a different mind-set in managing the firm, depending on the intra-family relationship (Le Breton-Miller and Miller 2013). If the involving family members share a harmonious relationship, their control and psychological bonds tend to remain strong and could focus the attention on the firm, including the financial performance and growth. However, if the family members lack cohesion due to some family disputes, such as the distribution of the ownership shares and/or management positions in the firm or interpersonal conflicts (Pieper 2010), a family firm is likely to struggle with allocating their attention between addressing the SEW goals, such as determining next successor(s), and the financial goal of business expansion.

If the family members share harmonious relationships, their SEW and financial goals are likely to maintain aligned to continue growing the business that can be sustained in the following generations, rather 
than struggling with the SEW issues, such as addressing the inter-family conflicts (Martin and Gomez-Mejia 2016). After the founding stage, a family business tends to have grown in size and resources that allow the expansion of the business and strategic activities (Le Breton-Miller and Miller 2013; Miller and Friesen 1984). Without the concerns of firm survival and family issues, it has the ability to expand sustainability activities to those without immediate financial returns, such as environmental protection (Berrone et al. 2010), innovation of product and service to benefit the health of customers (Cruz et al. 2014), or philanthropic donations to charity (Dou et al. 2014). For a post-founder family business with strong family cohesion and stable financial performance, it is able to explore different sustainability practices that the controlling family believes would bring in long-term SEW benefits, such as positive reputation and supports of broad stakeholder groups (Cennamo et al. 2012; Gomez-Mejia et al. 2011).

However, after the founders leave, if the remaining family members have conflicts over their SEW, such as fighting for the control of the firm or lacking quality relationship, it is likely to place a family business in a struggle over settling SEW goals of the family at the expense of financial goals of the firm (Martin and Gomez-Mejia 2016). The focus on SEW goals can have negative implications not only for the financial performance but also the sustainability activities of a family business. For instance, to preserve the family's control, a family business may have limited product innovation and diversification due to the constraint of the diversity practices, such as excluding non-family members in the key leadership roles (Vandekerkhof et al. 2015). This may explain the previously negative evidence regarding the sustainability activities of family businesses when the controlling family prevents the practices that may undermine its untenable SEW, such as introducing independent directors in the board or giving non-family employees' greater work autonomy (Cruz et al. 2014; Zientara 2017). Thus, if a post-founder family firm lacks cohesive relationship, the controlling family pays most attention on addressing SEW goals by imposing limitations on sustainability practices so that it can pursue SEW goals despite the potential conflicts with the financial goals. 
Proposition 2a: Sustainability strategy of a family business at the postfounder stage is likely to be expanded to those without direct financial returns if the involving family shares close relationships.

Proposition 2b: Sustainability strategy of a family business at the post-founder stage is likely to be limited to those without direct influence on the family's SEW if the involving family has conflicted relationships.

\subsection{Cousin Consortia Stage-Balance Between SEW and Financial Goals}

At the stage of cousin consortia, a family business is characterized by the involvement of more generations, including the third or later generation after the founders (Le Breton-Miller and Miller 2013). A family business at this stage tends to have grown to a more mature business than those at the previous stages, with a more formalized firm structure and more human resources (Gersick 1997). The governance structure tends to become more complex with the involvement of multiple members from different family branches and the inclusion of nonfamily and professional managers to address day-to-day operations. When a family business becomes mature, it tends to develop a formalized structure to effectively coordinate the complex structures and diverse resources (Miller and Friesen 1984). Through a formalized structure, a family business at the cousin consortia stage is more likely to develop a systematic evaluation of its SEW and financial goals through involving both family and non-family members in the governance structure (Dyer 2006).

With a formalized governance structure in place, a cousin consortia family business is expected to have a balanced strategy between SEW and financial goals (Holt et al. 2017). The increasing involvement of professional non-family members in the governance structure, such as independent directors in the board or non-family executive managers, raises the importance of financial performance in the decisionmaking process of a family business (Cabrera-Suárez et al. 2014). This allows a family business to have a more balanced view in its strategic 
decision-making by considering both SEW goals, valued by the family members, and financial returns, emphasized by non-family owners and managers (Minichilli et al. 2014).

Compared to the previous stages, a family firm at the cousin consortia stage is likely to develop a sustainability strategy that can balance its SEW and financial goals over long run (Le Breton-Miller and Miller 2016). With the monitoring of non-family owners and managers, the controlling family cannot limit the sustainability activities to only those that would directly benefit the family's SEW goals (Labelle et al., 2018), such as ignoring the diversity practices and employee empowerment to preserve the family's power (Cruz et al. 2014). Meanwhile, the continuous presence of the controlling family in the governance structure also ensures that non-family managers are not limiting sustainability activities to those with only direct financial returns, such as the improvement of products or services only. The involvement of the family members implies that the firm reputation is still connected to the reputation of the family, which is shaped by broader stakeholder groups beyond shareholders and investors (Block and Wagner 2014a), such as the local community and the general public. Therefore, a family business at the cousin consortia stage with a formalized governance structure is likely to develop a balanced sustainability strategy without over-emphasizing SEW or financial goals to have long-term financial and non-financial benefits.

Proposition 3: Sustainability strategy of a family firm at the cousin consortia stage is balanced between those that can benefit both SEW and financial returns.

\section{$4 \quad$ Directions for Future Research}

Future research can use the proposed framework as a foundation to advance the theoretical and empirical exploration of sustainability strategies of family businesses. First, future research can go beyond the general sustainability strategy discussed in the model. As corporate sustainability is meant to address multiple stakeholder groups (Aguilera 
et al. 2007), there can be a more refined examination on which specific stakeholder groups are affected by the change of strategic goals. For example, the sustainability performance scale of MSCI ESG database provides five common stakeholder groups: community, diversity, employee, environment, and product. Future research may apply this framework to see if the influences of the goal dynamic on different stakeholder groups are constant.

Second, in addition to the life stage of a family business, other family and/or business factors may have roles in shifting the strategic goal of a family business. One direction is to examine the conflicts between the family and working lives (Jennings and McDougald 2007): how the family members who are not involved in the firm structure affect the involving family members' decisions regarding the sustainability strategy of the business. Another direction is the institutional context in which a family business is located (Aguinis and Glavas 2012). The regulatory and normative pressure for corporate sustainability may differ at the national and local community levels and thus alter how the controlling family evaluates the importance of corporate sustainability to achieve the SEW and financial goals. The institutional factor can also be examined at the firm level by looking at the organizational culture, which would determine managers and employees' sense-making processes regarding the sustainability strategy and the related implementation (Maon et al. 2010). Future research can expand the framework to consider how other factors in family and firm domains would alter interaction between different strategic goals and the determination of the sustainability strategy.

Third, future empirical examination of this framework may require a mixed-method. The quantitative approach can be used to examine financial goal and some parts of SEW goals of a family business. The historical and relative financial performance can capture the financial pressure (Gómez-Mejía et al. 2007). The ratio of family and non-family members in ownership, management, and board structure in long run can denote whether a family firm has a stable SEW and a formal governance structure at different life stages (Gomez-Mejia et al. 2011). There are several databases, such as MSCI SEG and Thomson Reuters Asset4, that provide longitudinal observation of corporate sustainability 
activities. However, the family's relationship quality may require the qualitative approach, such as field observation of the family members' interaction, interviews with both family and non-family members, or content analysis of the internal communication documents, to better capture the emotional attachment and social relationships of the family (Berrone et al. 2012).

In summary, this chapter incorporates the temporal factor to discuss how financial and SEW goals interact over time to potentially explain the existing mixed evidence about sustainability activities of family businesses. The framework proposes that the evolution of strategic goals would determine how a family business allocate the attention and resource to the sustainability strategy. This chapter suggests that future research may need to consider the temporal dynamic between different strategic goals when examining the sustainability strategy, especially for a family business that sustains across generations.

\section{References}

Aguilera, R. V., Rupp, D. E., Williams, C. A., \& Ganapathi, J. (2007). Putting the $S$ back in corporate social responsibility: A multilevel theory of social change in organizations. Academy of Management Review, 32(3), 836-863.

Aguinis, H., \& Glavas, A. (2012). What we know and don't know about corporate social responsibility: A review and research agenda. Journal of Management, 38(4), 932-968.

Astrachan, J. H., Klein, S. B., \& Smyrnios, K. X. (2002). The F-PEC scale of family influence: A proposal for solving the family business definition problem. Family Business Review, 15(1), 45-58.

Astrachan, J. H., \& Shanker, M. C. (2003). Family businesses' contribution to the U.S. economy: A closer look. Family Business Review, 16(3), 211-219.

Berrone, P., Cruz, C., \& Gomez-Mejia, L. R. (2012). Socioemotional wealth in family firms: Theoretical dimensions, assessment approaches, and agenda for future research. Family Business Review, 25(3), 258-279.

Berrone, P., Cruz, C., Gomez-Mejia, L. R., \& Larraza-Kintana, M. (2010). Socioemotional wealth and corporate responses to institutional pressures: Do family-controlled firms pollute less? Administrative Science Quarterly, 55(1), 82-113. 
Block, J., \& Wagner, M. (2014a). Ownership versus management effects on corporate social responsibility concerns in large family and founder firms. Journal of Family Business Strategy, 5(4), 339-346.

Block, J., \& Wagner, M. (2014b). The effect of family ownership on different dimensions of corporate social responsibility: Evidence from large US firms. Business Strategy and the Environment, 23(7), 475-492.

Cabrera-Suárez, M. K., Déniz-Déniz, M. de L. C., \& Martín-Santana, J. D. (2014). The setting of non-financial goals in the family firm: The influence of family climate and identification. Journal of Family Business Strategy, 5(3), 289-299.

Campopiano, G., Massis, A. D., \& Chirico, F. (2014). Firm philanthropy in small- and medium-sized family firms the effects of family involvement in ownership and management. Family Business Review, 27(3), 244-258.

Cardon, M. S., Zietsma, C., Saparito, P., Matherne, B. P., \& Davis, C. (2005). A tale of passion: New insights into entrepreneurship from a parenthood metaphor. Journal of Business Venturing, 20(1), 23-45.

Carney, M., Van Essen, M., Gedajlovic, E. R., \& Heugens, P. P. M. A. R. (2015). What do we know about private family firms? A meta-analytical review. Entrepreneurship Theory and Practice, 39(3), 513-544.

Carroll, R. J., Primo, D. M., \& Richter, B. K. (2016). Using item response theory to improve measurement in strategic management research: An application to corporate social responsibility. Strategic Management Journal, 37(1), 66-85.

Cassar, G. (2007). Money, money, money? A longitudinal investigation of entrepreneur career reasons, growth preferences and achieved growth. Entrepreneurship \& Regional Development, 19(1), 89-107.

Cennamo, C., Berrone, P., Cruz, C., \& Gomez-Mejia, L. R. (2012). Socioemotional wealth and proactive stakeholder engagement: Why family-controlled firms care more about their stakeholders. Entrepreneurship: Theory \& Practice, 36(6), 1153-1173.

Chua, J. H., Chrisman, J. J., \& Sharma, P. (1999). Defining the family business by behavior. Entrepreneurship: Theory \& Practice, 23(4), 19-39.

Cooper, A. C. (1981). Strategic management: New ventures and small business. Long Range Planning, 14(5), 39-45.

Cruz, C., Larraza-Kintana, M., Garcés-Galdeano, L., \& Berrone, P. (2014). Are family firms really more socially responsible? Entrepreneurship Theory and Practice, 38(6), 1295-1316. 
Deephouse, D. L., \& Jaskiewicz, P. (2013). Do family firms have better reputations than non-family firms? An integration of socioemotional wealth and social identity theories. Journal of Management Studies, 50(3), 337-360.

Dou, J., Zhang, Z., \& Su, E. (2014). Does family involvement make firms donate more? Empirical evidence from Chinese private firms. Family Business Review, 27(3), 259-274.

$\mathrm{Du}, \mathrm{X}$. (2015). Is corporate philanthropy used as environmental misconduct dressing? Evidence from Chinese family-owned firms. Journal of Business Ethics, 129(2), 341-361.

Dyer, W. G. (2006). Examining the "family effect" on firm performance. Family Business Review, 19(4), 253-273.

Eccles, R. G., Ioannou, I., \& Serafeim, G. (2014). The impact of corporate sustainability on organizational processes and performance. Management Science, 60(11), 2835-2857.

Feliu, N., \& Botero, I. C. (2016). Philanthropy in family enterprises: A review of literature. Family Business Review, 29(1), 121-141.

Gersick, K. E. (1997). Generation to generation: Life cycles of the family business. Boston, MA: Harvard Business Press.

Gomez-Mejia, L. R., Cruz, C., Berrone, P., \& De Castro, J. (2011). The bind that ties: Socioemotional wealth preservation in family firms. Academy of Management Annals, 5(1), 653-707.

Gómez-Mejía, L. R., Haynes, K. T., Núñez-Nickel, M., Jacobson, K. J. L., \& Moyano-Fuentes, J. (2007). Socioemotional wealth and business risks in family-controlled firms: Evidence from Spanish olive oil mills. Administrative Science Quarterly, 52(1), 106-137.

Gond, J.-P., Palazzo, G., \& Basu, K. (2009). Reconsidering instrumental corporate social responsibility through the mafia metaphor. Business Ethics Quarterly, 19(1), 57-85.

Hammond, N. L., Pearson, A. W., \& Holt, D. T. (2016). The quagmire of legacy in family firms: Definition and implications of family and family firm legacy orientations. Entrepreneurship Theory and Practice, 40(6), 1209-1231.

Harrison, J. S., \& Freeman, R. E. (1999). Stakeholders, social responsibility, and performance: Empirical evidence and theoretical perspectives. Academy of Management Journal, 42(5), 479-485.

Hauswald, H., \& Hack, A. (2013). Impact of family control/influence on stakeholders' perceptions of benevolence. Family Business Review, 26(4), 356-373. 
Holt, D. T., Pearson, A. W., Carr, J. C., \& Barnett, T. (2017). Family firm(s) outcomes model: Structuring financial and nonfinancial outcomes across the family and firm. Family Business Review, 30(2), 182-202.

Jennings, J. E., \& McDougald, M. S. (2007). Work-family interface experiences and coping strategies: Implications for entrepreneurship research and practice. Academy of Management Review, 32(3), 747-760.

Labelle, R., Hafsi, T., Francoeur, C., \& Amar, W. B. (2018). Family firms' corporate social performance: A calculated quest for socioemotional wealth. Journal of Business Ethics, 148(3), 511-525.

Le Breton-Miller, I., \& Miller, D. (2013). Socioemotional wealth across the family firm life cycle: A commentary on "Family business survival and the role of boards". Entrepreneurship Theory and Practice, 37(6), 1391-1397.

Le Breton-Miller, I., \& Miller, D. (2016). Family firms and practices of sustainability: A contingency view. Journal of Family Business Strategy, 7(1), 26-33.

Mandl, I. (2008). Overview of family business relevant issues. Vienna: European Commission.

Maon, F., Lindgreen, A., \& Swaen, V. (2010). Organizational stages and cultural phases: A critical review and a consolidative model of corporate social responsibility development. International Journal of Management Reviews, 12(1), 20-38.

Martin, G., \& Gomez-Mejia, L. (2016). The relationship between socioemotional and financial wealth: Re-visiting family firm decision making. Management Research: Journal of the Iberoamerican Academy of Management, 14(3), 215-233.

McGuire, J., Dow, S., \& Ibrahim, B. (2012). All in the family? Social performance and corporate governance in the family firm. Journal of Business Research, 65(11), 1643-1650.

Miller, D., \& Friesen, P. H. (1984). A Longitudinal study of the corporate life cycle. Management Science, 30(10), 1161-1183.

Minichilli, A., Nordqvist, M., Corbetta, G., \& Amore, M. D. (2014). CEO succession mechanisms, organizational context, and performance: A socio-emotional wealth perspective on family-controlled firms. Journal of Management Studies, 51(7), 1153-1179.

Peake, W. O., Cooper, D., Fitzgerald, M. A., \& Muske, G. (2017). Family business participation in community social responsibility: The moderating effect of gender. Journal of Business Ethics, 142(2), 325-343. 
Pieper, T. M. (2010). Non solus: Toward a psychology of family business. Journal of Family Business Strategy, 1(1), 26-39.

PwC. (2016). Family business survey 2016 - The "missing middle": Bridging the strategy gap in family firms. London, UK.

Spence, L. J. (2016). Small business social responsibility expanding core CSR theory. Business and Society, 55(1), 23-55.

Vandekerkhof, P., Steijvers, T., Hendriks, W., \& Voordeckers, W. (2015). The effect of organizational characteristics on the appointment of nonfamily managers in private family firms: The moderating role of socioemotional wealth. Family Business Review, 28(2), 104-122.

Zientara, P. (2017). Socioemotional wealth and corporate social responsibility: A critical analysis. Journal of Business Ethics, 144(1), 185-199. 